\title{
Stønad ved barns sykdom - mer besvær enn støtte?
}

\author{
Siste års endringer i forskrift og rundskriv i folketrygdens kapittel 9 har ført til betydelig og for mange ukjent \\ strammere fortolkning, særlig hva gjelder pleiepenger. Innstrammingene medfører vansker for både foreldre \\ og barneleger. Kapittel 9 bør revideres slik at pleiepenger ytes så lenge det er nødvendig uavhengig av dia- \\ gnose og varighet.
}

Vi arbeider med somatisk syke barn og deres foreldre for å forebygge uheldige psykososiale konsekvenser av sykdom og for å fremme god sykdomsmestring. I de senere årene er ulike sosialmedisinske problemstillinger i økende grad blitt det mest sentrale temaet i våre samtaler med foreldre. Sykehusleger må bruke mye tid til å utferdige nødvendige legeerklæringer ved utfylling av søknadsskjemaer og ved ankesaker.

Ved barns sykdom rammes et helt familiesystem. Barnet er avhengig av foreldrenes fysiske og psykiske omsorg, og familien av opprettholdelse av inntekt. Foreldrenes rettigheter er nedfelt i folketrygdlovens kapittel 9 om «Stønad ved barns og andre nære pårørendes sykdom» (1), som i utgangspunktet skal dekke foreldrenes behov ved barnets sykdom. Kapitlet omfatter omsorgspenger ved barns eller barnepassers sykdom, pleiepenger når et barn er innlagt i helseinstitusjon eller trenger pleie i hjemmet, samt opplæringspenger til foreldre med et funksjonshemmet eller langvarig sykt barn (2).

Allerede i 1991 ble vansker med sykepenger ved barns sykdom beskrevet i Tidsskriftet (3). Konklusjonen til to barneleger var denne: «Det langsiktige målet må [...] være at myndighetene innser at lov om folketrygd må gi muligheter til sykepenger for alle foreldre uansett diagnose i alle tilfeller der barn er syke, og for hele sykdommens varighet. Bare på den måten vil det bli samsvar mellom Forskrift om barn på sykehus, og barnets muligheter til å få disse forskriftene oppfylt.»

Ved innføringen av kapittel 9 i 1998 trodde mange at dette målet var nådd. Siden har det skjedd betydelige endringer. Formålet med endringene har vært å styrke rettighetene til småbarnsforeldre. Det er nå en økt harmonisering med forskriften om barns opphold i helseinstitusjon (4) ved at minst en av foreldrene kan være sammen med barnet når barnet er innlagt $i$ helseinstitusjon uavhengig av varighet. Kapittel 9 gir også mulighet for sykepenger ved barns sykdom til en større personkrets ut fra erkjennelsen om at familiestrukturer er under endring. Det ytes stønad så lenge det er nødvendig for barnet, men ikke som varig ytelse. Det har derfor vært brukt mye skjønn, og loven er gjennom mange år blitt tolket liberalt.
De siste årene har det skjedd innstramminger i fortolkningen og endringer i rundskriv og forskrift. Formålet med denne artikkelen er å gi en oversikt over kapittel 9 slik den er og praktiseres i dag. Pleiepenger vil bli særlig drøftet, ettersom en strammere fortolkning synes å gi økende problemer for både foreldre og medisinsk fagpersonell. Vi vil synliggiøre hvor begrensningene trer tydeligst frem og drøfte forslag til endringer.

\section{Kapittel 9 i folketrygdloven}

Formålet med stønad etter kapittel 9 i folketrygdloven er å kompensere for tapt arbeidsinntekt for yrkesaktive foreldre ved barns eller barnepassers sykdom. For å få rett til stønad må medlemmet ha hatt arbeidsinntekt eller annen pensjonsgivende inntekt i minst fire uker umiddelbart før fraværet fra arbeidet og hvor inntektsgrunnlaget utgjør minst $50 \%$ av folketrygdens grunnbeløp (2).

Videre er vilkåret at barnet trenger kontinuerlig tilsyn og pleie, og at foreldrene står for minst $50 \%$ av tilsynet hver for seg eller til sammen. I det følgende gis utfyllende kommentarer til hver enkelt paragraf (tab 1).

\section{§ 9-5 Omsorgspenger ved barns}

eller barnepassers sykdom

Med «omsorg» menes her at arbeidstakeren enten har omsorgen alene, delt omsorg med den andre forelderen eller delt omsorg med ny ektefelle/partner/samboer som man har felles barn med. Hvis foreldrene har delt foreldreomsorg med $50 \%$ hver, har begge en selvstendig rett til omsorgspenger fra arbeidsgiver.

\section{\& 9-6 Omsorgspenger ved kronisk sykt} eller funksjonshemmet barn

Som kronisk sykt eller funksjonshemmet barn regnes barn som lider av en tilstand som omfattes av egen liste på 27 diagnoser (ramme 1). Hvis foreldre har omsorg for kronisk syke barn, har de ti dager hver fra arbeidsgiver og ti ekstra dager hver fra NAV for hvert kronisk sykt barn per år. I tidligere lov var det bare den som hadde den daglige omsorgen for barnet, som hadde rett til utvidet antall dager. Foreldre som er alene om omsorgen, kan overføre ti av dagene til ny ektefelle/samboer/partner dersom forholdet har vart i minst 12 måneder. Ved avtalt samvær kan foreldre forholdsmessig fordele omsorgspengedagene mellom seg.

\section{Ramme 1}

Liste over sykdom eller funksjonshemning som definerer kronisk syke eller funksjonshemmede barn i kapittel 9 i folketrygdloven

1. Betydelige hjertesykdommer

2. Kreftsykdommer

3. Betydelige hjerneskader, for eksempel cerebral parese, epilepsi, psykisk utviklingshemning, degenerative hjernesykdommer

4. Betydelige lammelser

5. Muskeldystrofier og annen alvorlig muskelsykdom

6. Diabetes mellitus, Føllings sykdom og andre alvorlige metabolske sykdommer

7. Autisme og andre barnepsykoser

8. Kronisk nyresykdom

9. Residiverende urinveisinfeksjoner

10. Kroniske anemier

11. Kronisk blødersykdom

12. Immundefekter

13. Kronisk leversykdom

14. Leddgikt og andre kroniske revmatiske sykdommer

15. Lupus erythematosus disseminatus

16. Astma og annen kronisk lungesykdom

17. Osteogenesis imperfecta og andre skjelettsykdommer med betydelige funksjonshemninger

18. Blinde og svaksynte barn

19. Døve og sterkt tunghørte barn

20. Cystisk fibrose

21. Ulcerøs kolitt

22. Crohns sykdom

23. Cøliaki i aktiv fase

24. Addisons sykdom

25. Cushings sykdom

26. Alvorlige medfødte misdannelser

27. Andre betydelige kroniske sykdommer og funksjonshemninger enn de som er nevnt ovenfor 


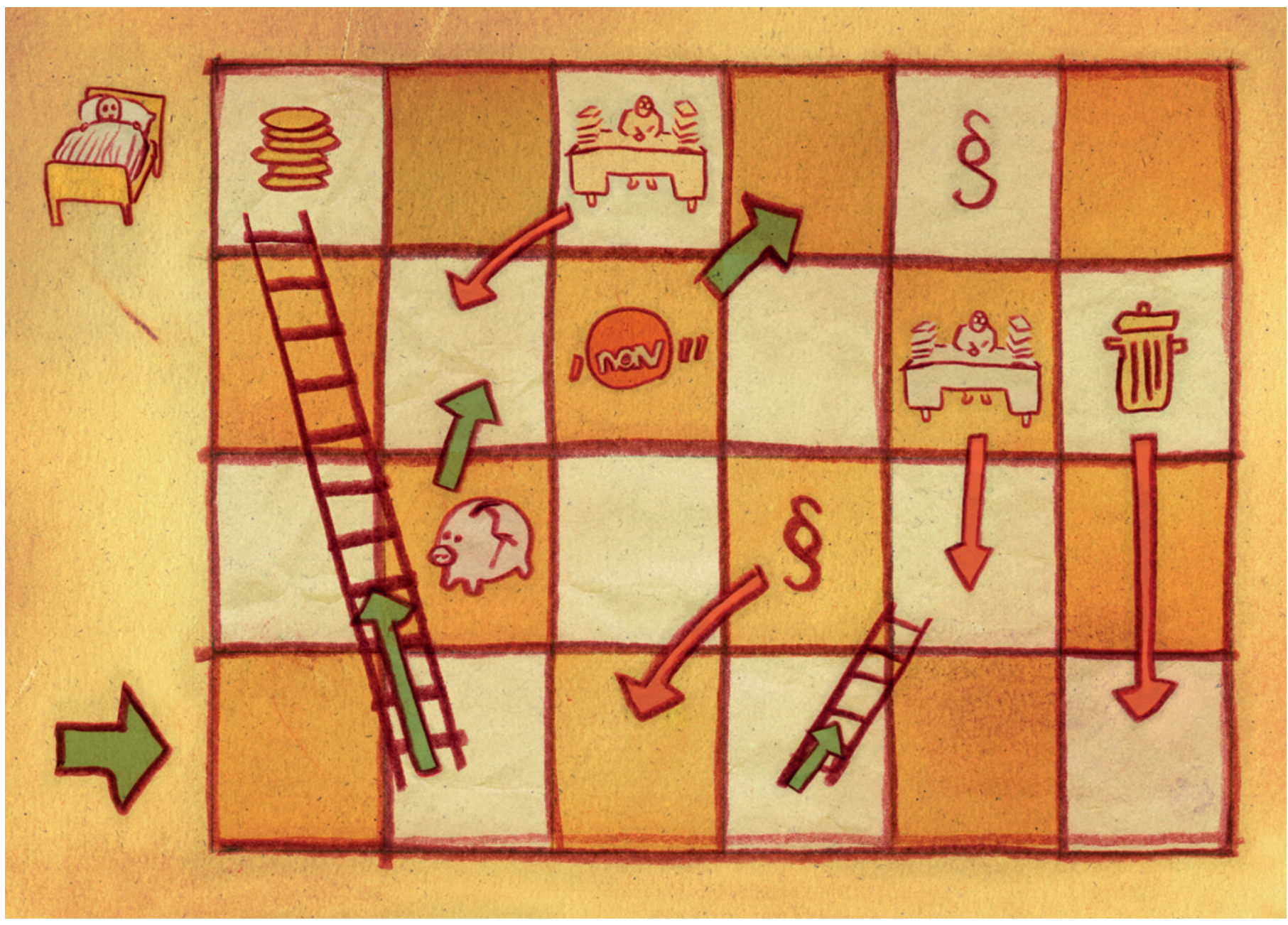

Illustrasjon Stein Løken

\section{§ 9-10 Pleiepenger}

ved mindre alvorlig sykt barn

Pleiepenger skal ikke gis der det foreligger et varig pleiebehov, men skal kun gis for avgrensede perioder. Fra 2008 er det ikke lenger et vilkår at barnet må ha vært innlagt $i$ helseinstitusjon for å få pleiepenger fra 8. dag. Men selve legeerklæringen må skrives i tilknytning til den aktuelle innleggelse eller polikliniske undersøkelse.

Denne paragrafen er vag. Det er presisert mindre alvorlig sykdom, men barnet må ha døgnkontinuerlig tilsyns- og pleiebehov. Klinisk erfaring viser at det er skjønn og vilkårlighet som preger vedtak etter $\S 9-10$.

\section{§ 9-11 Pleiepenger ved alvorlig sykt barn}

Det er ikke et vilkår at barnet må være innlagt i sykehus. Stønad etter § 9-11 kan derfor også ytes i hjemmet hvis det er behov for døgnkontinuerlig tilsyn og pleie fra en eller begge foreldre. Det presiseres også at barnet ikke må ha vært innlagt først; dette fordi barnets helsetilstand en tid etter utskrivning kan innebære at foreldrene fyller vilkårene for ny periode med pleiepenger etter § 9-11 uten at barnet må legges inn først.

Rikstrygdeverket ga i sin tid generelle retningslinjer for hvilke åtte diagnoser som regnes som alvorlige eller livstruende (ramme 2). I 2008 kom det en endring i diagnoselisten om «for tidlig fødte barn, barn med alvorlige medfødte misdannelser og andre kritisk syke nyfødte barn». Da den medisinske situasjonen ofte her er uavklart, er hendelsesforløpet delt opp i tre faser med henblikk på stønad (ramme 3 ).

\section{$\S$ 9-11, 2. ledd: Pleiepenger ved varig alvorlig sykt barn}

En tilføyelse av nytt annet ledd kom i 2006. Hovedregelen er at det ikke skal utbetales pleiepenger ved varig pleiebehov. Sykdommer med antatt varighet over to år anses som varige og gir således ikke foreldrene rett til pleiepenger. Den aktuelle ytelsen blir da hjelpestønad.

Unntak gjelder imidlertid når barnets tilstand forverres eller kommer inn i en ustabil fase. Det presiseres at det kan ytes pleiepenger i startfasen av en varig alvorlig sykdom. Hvis et barn lider av alvorlig, progredierende sykdom, kan det foreligge en kontinuerlig rett til pleiepenger.

\section{§ 9-11, 4. ledd: Fortsatt rett til pleiepenger} inntil tre måneder dersom barnet dør

Denne ytelsen er ny fra 2010. Dersom foreldre har mottatt fulle pleiepenger i minst tre år, har de rett til samme ytelse $i$ tre måneder etter at pleieforholdet opphørte fordi barnet dør. Har man i mellomtiden hatt sykepenger for egen sykdom eller foreldrepenger, regnes det som sammenhengende periode dersom pleieforholdet har vært sammenhengende.

\section{§ 9-11a Graderte pleiepenger}

Stønad etter § 9-11a trådte i kraft februar 2006. Foreldre kan ikke arbeide mer enn $50 \%$ etter denne paragrafen. Hvis barnet er mer enn $50 \%$ i barnehagen eller på skolen, faller vilkåret om graderte pleiepenger bort. Foreldre kan dele graderte pleiepenger mellom seg så lenge den totale graden er $50 \%$ eller mer. Den ene av foreldrene kan ikke motta mindre enn $20 \%$ pleiepenger.

\section{§ 9-13 Opplæringspenger ved omsorg for} funksjonshemmet eller langvarig sykt barn Opplæringspenger gis foreldre som har omsorg for et funksjonshemmet eller langvarig sykt barn, for deltakelse på kurs eller opplæring ved godkjent helseinstitusjon eller offentlig spesialpedagogisk kompetansesenter. Vilkåret er at opplæringen må være nødvendig for at foreldrene skal kunne ta seg av barnet. Det kan også ytes opplæringspenger ved utenlandsreiser som arrangeres av norske helsemyndigheter. 
Paragrafen inneholder også en videre tolking av hvem som kan få opplæringspenger, inkludert besteforeldre og liknende. Dersom foreldrene er skilt, kan den som ikke har omsorgen også få opplæringspenger. Dersom den som er alene om omsorgen for barnet har ny samboer, kan også samboer få opplæringspenger.

Hvem kan skrive legeerklæring for pleie- og opplæringspenger?

I § 9-14 står det at legeerklæring må utstedes fra den sykehusavdeling som har ansvaret for behandlingen av barnet, og at erklæringen må redegjøre for barnets situasjon og behovet for foreldrenes nærvær.

Ved alle paragrafene gjelder en generell regel om tre måneders tilbakevirkende kraft når barnelegen skriver legeerklæringen. Som følge av lang ventetid ved behandling av søknader, må foreldrene selv ta avgjørelsen om de skal bli borte fra jobb dersom de får avslag på pleiepenger/opplæringspenger og således ikke refusjon til arbeidsgiver der det er forskuttert lønn.

\section{Diskusjon}

Formålet med folketrygdens kapittel 9 er å kompensere for tapt arbeidsinntekt når et barn blir sykt. Pleiepenger ytes så lenge barnet trenger kontinuerlig tilsyn og pleie, men skal ikke gis som varig ytelse. Senere års endringer av forskrift og rundskriv har medført betydelige innstramminger av fortolkningen samtidig som bruken av lokalt skjønn har økt. Dette har ført til flere begrensninger som følge av paragrafenes definisjon av varig, alvorlig sykdom, startfasen av en sykdom, progredierende sykdom og gradering av tilsyn. Foreldre til akutt livstruende syke barn får pleiepenger, mens ved kronisk og progredierende sykdom ytes dette bare i startfasen og hvis tilstanden forverrer seg.

Varig, alvorlig sykdom

Diagnoselistene som definerer varig og alvorlig sykdom er ikke endret på over 20 år. Det ikke er nok å sammenlikne et aktuelt pleiebehov med sykdom som står på listen for å kunne skrive ut pleiepengeattest på en sykdom som ikke er nevnt i oversikten. Det savnes derfor en regelmessig gjennomgang av de aktuelle diagnoser ved et fagutvalg/høringsinstans for vurdering av betimelige endringer.

Ved varig, alvorlig sykdom ytes pleiepenger i startfasen og når sykdommen er i en ustabil og forverret fase. Bakgrunnen for denne innstramming ble gjort for å avgrense retten til pleiepenger. Da tolkingen av «ustabil, forverret fase» er basert på skjønn, er det derfor gjennom dagens praksis vilkårlighet som avgjør om stønad innvilges eller avslås. Dette innebærer stor uforutsigbarhet for foreldre og barneleger.

\section{Startfasen}

Det er i de senere år etablert en praksis hvor startfasen anses å ha inntil seks måneders varighet fra sykdomsdebut av en varig, alvorlig sykdom - til tross for at tidsaspektet av en startfase ikke er nedfelt i forskrift eller rundskriv. Det anvendes derfor også her skjønn, noe som fører til mange avslag og tidkrevende ankeprosesser. Det ytes ikke pleiepenger for det tidsrommet det ankes over, noe som kan medføre store økonomiske vansker for foreldrene. Vi savner en klarere og utvidet tidsangivelse.

\section{Progredierende sykdom}

Presisering av at det kan foreligge en kontinuerlig rett til pleiepenger hvis barnet lider av en alvorlig, progredierende sykdom, kom etter en kjennelse i Trygderetten der foreldre til et barn med Spielmeyer-Vogts syndrom fikk innvilget varige pleiepenger (5). Det foreligger her en såkalt femmedlemskjennelse som innebærer at saken har stor prinsipiell betydning. Derfor åpnes det nå for muligheten for varige pleiepenger ved progredierende sykdom. Barnelegen må i legeerklæringen om pleiepenger være svært konkret i sin beskrivelse av at sykdommen medfører raskt progredierende tap av ferdigheter mot fullstendig hjelpeløshet og tidlig død. Dersom disse vilkårene ikke er oppfylt, får foreldre til denne pasientgruppen pleiepenger bare i startfasen og når barnet er i en ustabil, forverret fase.

Da formuleringen «varig og progredierende sykdommer» ble tatt inn som $\S 9-11$, 2. ledd ble det presisert at sykdommen måtte være $\mathrm{i}$ «en ustabil fase». I forhold til en slik begrensning av rett til pleiepenger, er det å bemerke at mens pleiepenger i 2010 samlet utgjorde 499 millioner kroner, er tilsvarende tall for arbeidstakeres sykepenger 32 milliarder kroner. Pleiepenger utgjør dermed ca. 1-2\% av sykepengene. Dette er en særdeles sårbar pasientgruppe. Det er derfor bekymringsfullt at det har vært nødvendig med en slik begrensning.

\section{Graderte pleiepenger}

Graderte pleiepenger tolkes rigid til 50\% ytelse, noe som betyr at foreldre kan jobbe maksimum $50 \%$. Vi erfarer her en betydelig økning i avslag til tross for at det er rimelig å anta at det må være samfunnsøkonomisk lønnsomt om foreldre i perioder kan jobbe $75 \%$; da kan barnet være i barnehagen eller på skolen i tilsvarende prosentdel. Dette vil omfatte flere foreldre, men gi lavere ytelser. Bakgrunnen for at denne paragrafen er opprettet, er nettopp å gi foreldre muligheten til å delta på arbeidsmarkedet selv om barnet trenger kontinuerlig tilsyn og pleie. I et stramt arbeidsmarked bør foreldre selv få velge $i$ hvilken grad og på hvilken måte de skal ta seg av barnet når det blir sykt. Vi anbefaler derfor en endring av $§ 9-11$ a ved at grade-

\section{Ramme 2}

Diagnoser/skader som regnes som alvorlige/livstruende i kapittel 9 i folketrygdloven

1. Kreftsyke barn

2. Barn med store trafikkskader eller andre alvorlige skader

3. For tidlig fødte barn, barn med alvorlige medfødte misdannelser og andre kritisk syke nyfødte barn

4. Barn med hjertefeil

5. Store funksjonshemninger

6. Alvorlig astma

7. Psykiatriske lidelser

8. Livstruende og andre alvorlige sykdommer som ikke er nevnt ovenfor

ringen går ned til $20 \%$, dvs. at foreldre kan arbeide opptil $80 \%$.

\section{Konklusjon}

Som følge av disse innstrammingene erfarer vi nå at foreldrene blir sykmeldte med egen diagnose for å kunne ta seg av barnet. Fastlegene antas å ha kommet $\mathrm{i}$ et etisk dilemma. Erfaringsmessig får foreldrene som oftest en psykisk P-kode-diagnose (ICPC), noe som igjen kan føre til vansker ved senere tegning av forsikring og jobbsøknader. I tillegg «spiser» foreldrene av egne rettigheter ved at de kan gå sykemeldt kun i 52 uker og deretter må over på arbeidsavklaringspenger med $66 \%$ av inntektsgrunnlaget. Utgiftene til sykepenger vil øke. Dermed vil ikke begrensningen av pleiepenger få den tilsik-

\section{Ramme 3}

Ulike faser i forløpet for for tidlig fødte barn, barn med alvorlige medfødte misdannelser og andre kritisk syke nyfødte barn der det kan gis støtte etter kapittel 9 i folketrygdloven

- Avklaringsperiode på sju dager med pleiepenger til begge foreldre (§ 9-11)

- Der intensivbehandling er nødvendig, gis det fortsatt pleiepenger (§ 9-11)

- Vokse- og grofase hvor barnet fortsatt kan ha behov for behandling, men ikke lenger er alvorlig, livstruende sykt, kan det gis opplæringspenger for at foreldre skal kunne få nødvendig opplæring for å kunne ta seg av barnet (§ 9-13)

- Når barnet kommer hjem, kan den ene forelderen få pleiepenger, samtidig med at den andre mottar foreldrepenger så lenge vilkårene for øvrig er oppfylt (§ 9-10) 
Tabell 1 Kapittel 9 - Stønader ved barns sykdom (2)

\begin{tabular}{|c|c|c|c|}
\hline Paragraf & Vilkår & Omfang & Varighet \\
\hline § 9-5; Omsorgspenger & $\begin{array}{l}\text { Nødvendig tilsyn/pleie av sykt barn } \\
\text { i hjemmet/helseinstitusjon når } \\
\text { a. den som har tilsynet er } \\
\text { - syk } \\
\text { - forhindret fra å ha tilsyn fordi vedkom- } \\
\text { mende følger annet barn } \\
\text { til utredning/innleggelse helseinstitu- } \\
\text { sjon, eller } \\
\text { b. barnet pga. sykdom trenger oppfølging } \\
\text { i form av annet legebesøk selv om } \\
\text { barnet ikke er sykt aktuelle dag }\end{array}$ & $\begin{array}{l}\text { < } 3 \text { barn: } 10 \text { dager/år } \\
\geq 3 \text { barn: } 15 \text { dager/år } \\
\text { Hvis aleneforelder: Dobles antall dager/år } \\
\text { (20 mot } 30 \text { dager/år) }\end{array}$ & $\begin{array}{l}\text { T.o.m. kalender- } \\
\text { året barnet } \\
\text { fyller } 12 \stackrel{\circ}{\mathrm{r}}\end{array}$ \\
\hline $\begin{array}{l}\text { §9-6; Omsorgspenger; } \\
\text { utvidet }\end{array}$ & $\begin{array}{l}\text { Som over, men ved kronisk sykt eller } \\
\text { funksjonshemmet barn; se egen liste } \\
\text { (ramme 1) }\end{array}$ & $\begin{array}{l}\text { Per sykt barn: } 10 \text { ekstra dager/år } \\
\text { Hvis aleneforelder: Dobles antall dager/år }\end{array}$ & $\begin{array}{l}\text { T.o.m. kalender- } \\
\text { året barnet fyller } \\
18 \text { år; gjelder for ett } \\
\text { år av gangen }\end{array}$ \\
\hline $\begin{array}{l}\text { § 9-10; Pleiepenger } \\
\text { v/mindre alvorlig sykt barn }\end{array}$ & $\begin{array}{l}\text { Behov for døgnkontinuerlig tilsyn/pleie } \\
\text { i hjemmet/helseinstitusjon } \\
\text { - v/mindre alvorlig sykt barn }\end{array}$ & $\begin{array}{l}\text { Ytes f.o.m. 8. dag; de første } 7 \text { dager dekkes av } \S 9-5 \text {. } \\
\text { Ytes en av foreldrene av gangen. } \\
\text { Hvis barnet bor fast hos den ene } \\
\text { av skilte foreldre, har begge rett til pleiepenger. } \\
\text { Avgrenset periode; ikke varig pleie/tilsyn }\end{array}$ & $\begin{array}{l}\text { T.o.m. } 12 \text { år, t.o.m. } \\
18 \text { år ved kronisk } \\
\text { sykdom og funk- } \\
\text { sjonshemning }\end{array}$ \\
\hline $\begin{array}{l}\text { §9-11; Pleiepenger } \\
\text { v/alvorlig sykt barn }\end{array}$ & $\begin{array}{l}\text { Behov for døgnkontinuerlig tilsyn/pleie } \\
\text { i hjemmet/helseinstitusjon } \\
\text { - v/alvorlig, livstruende sykdom; } \\
\text { se egen liste (ramme 2) }\end{array}$ & $\begin{array}{l}\text { Ytes f.o.m. første dag. } \\
\text { Kan ytes begge foreldre samtidig. } \\
\text { Også v/mistanke om alvorlig, livstruende sykdom. } \\
\text { Avgrenset periode; ikke varig pleie/tilsyn }\end{array}$ & $\begin{array}{l}\text { T.o.m. } 18 \text { år; ingen } \\
\text { aldersgrense } \\
\text { v/psykisk utvik- } \\
\text { lingshemning }\end{array}$ \\
\hline $\begin{array}{l}\text { § 9-11; annet ledd: Pleie- } \\
\text { penger v/varig alvorlig sykt } \\
\text { barn }\end{array}$ & $\begin{array}{l}\text { Ved varig alvorlig sykdom kun i startfasen, } \\
\text { ved forverring/progrediering, eller i usta- } \\
\text { bil fase }\end{array}$ & Som over & Som over \\
\hline $\begin{array}{l}\text { §9-11a; Graderte pleie- } \\
\text { penger }\end{array}$ & $\begin{array}{l}\text { Fortsatt behov for døgnkontinuerlig } \\
\text { tilsyn/pleie, men deler av dagen }(<50 \%) \\
\text { tilsyn/pleie fra andre enn foreldre (skole, } \\
\text { barnehage) }\end{array}$ & Som over & Som over \\
\hline $\begin{array}{l}\S 9-11 \text {; fjerde ledd: Pleie- } \\
\text { penger v/barns død }\end{array}$ & $\begin{array}{l}\text { Ved et barns død. } \\
\text { Hvis mottatt fulle pleiepenger i minst } 3 \text { år }\end{array}$ & Rett til ytelse 3 md. etter barnets død & $\begin{array}{l}3 \text { md. etter } \\
\text { barnets død }\end{array}$ \\
\hline § 9-13; Opplæringspenger & $\begin{array}{l}\text { Kurs/opplæring nødvendig for tilsyn/pleie } \\
\text { v/langvarig sykdom/funksjonshemning }\end{array}$ & $\begin{array}{l}\text { Fra første dag. } \\
\text { Begge foreldre, også besteforeldre. } \\
\text { Hvis utlandet, maks } 2 \text { uker }\end{array}$ & $\begin{array}{l}\text { Ingen } \varnothing \text { vre alders- } \\
\text { grense; også utover } \\
18 \text { år }\end{array}$ \\
\hline
\end{tabular}

tede konsekvens, nemlig reduserte statlige utgifter. I tillegg til den psykiske belastningen det er å ha et barn med alvorlig, varig eller progredierende sykdom påføres foreldrene betydelig tilleggsbelastning ved ikke å vite om og når det innvilges pleiepenger. Dette harmonerer ikke med at pleiepenger skal gis så lenge barnet trenger kontinuerlig tilsyn og pleie.

Intensjonene med kapittel 9 var å kompensere for tapt arbeidsinntekt ved barns sykdom og å utvide personkretsen som kunne få stønad. Diagnosekriteriene og reglene for når pleiepenger kan ytes og varigheten av ytelsene, er imidlertid meget uklare. Kaasa-utvalget foreslo i 2011 at eksisterende pleiepengeordning bør omfatte alle barn under 18 år med varig, alvorlig lidelse og graderes fra $20 \%$ til $50 \%$ som varig ytelse (6). Vi mener at det ikke skal handle om særlige regler for denne pasientgruppen, men at den skal ha selvfølgelige og likestilte rettigheter som andre pasientgrupper. Dermed gjenstår den største og viktigste endringen, nemlig at pleiepenger må ytes så lenge det er nødvendig uavhengig av diagnose og varighet.

\section{Sissel Berg Haveraaen}

sissel.berg.haveraaen@ous-hf.no

Seksjon for psykosomatikk og CL-barnepsykiatri Barneavdeling for nevrofag

Kvinne- og barneklinikken

Oslo universitetssykehus, Rikshospitalet

\section{Trond H. Diseth}

Seksjon for psykosomatikk og CL-barnepsykiatri Barneavdeling for nevrofag Kvinne- og barneklinikken

Oslo universitetssykehus, Rikshospitalet og

Universitetet i Oslo

Sissel Berg Haveraaen (f. 1953) er cand.mag. og klinisk sosionom ved Seksjon for psykosomatikk og CL-barnepsykiatri, Oslo universitetssykehus, Rikshospitalet, med spesialkompetanse i familieterapi for familier og foreldre til alvorlig og kronisk somatisk syke barn og unge. Forfatter har fylt ut ICMJE-skjemaet og oppgir ingen interessekonflikter.

Trond H. Diseth (f. 1957) er spesialist i barneog ungdomspsykiatri med spesialkompetanse psykososiale faktorer ved alvorlig og kronisk somatisk syke barn og unge og deres familier.
Han er avdelingsoverlege ved Kvinne- og barneklinikken, Oslo universitetssykehus, Rikshospitalet og professor ved Universitetet i Oslo. Forfatter har fylt ut ICMJE-skjemaet og oppgir ingen interessekonflikter.

\section{Litteratur}

1. NAV. Lover og regler. Kapittel 9 i folketrygdloven. Stønader ved barns og andre nære pårørendes sykdom. www.nav.no (25.11.2011).

2. Kjønstad A. Folketrygdloven med kommentarer 2. utg. Oslo: Gyldendal, 2007: 412-6.

3. Bratlid D, Borgen G. Sykepenger til foreldre ved barns sykdom. Tidsskr Nor Lægeforen 1991; 111 2563-7.

4. Helsedepartementet 2000. Forskrift om barns opphold i helseinstitusjon (1.12.2000 - nr 1217), hjemlet i Spesialisthelsetjenesteloven m.m. av 2. juli $1999 \mathrm{nr} 61 \S 3-6$

5. Trygderetten 2005. Kjennelse. TRR-2004-3634. www.trygderetten.no (25.11.2011)

6. Norges offentlige utredninger. Når sant skal sies om pårørendeomsorg. Fra usynlig til verdsatt og inkludert. NOU 2011: 17. kapittel 12: 87-8.

Mottatt 12.1. 2012, første revisjon innsendt 6.3. 2012, godkjent 16.5. 2012. Medisinsk redaktør Petter Gjersvik. 